Wahana Didaktika Vol. 16 No.3 September 2018 : 366-375

\title{
INTEGRASI KEARIFAN LOKAL DALAM PEMBELAJARAN MATEMATIKA DENGAN PENDEKATAN CONTEKSTUAL LEARNING
}

\author{
Oleh: Lusiana \\ (Dosen Universitas PGRI Palembang) \\ Email :luusiiana@yahoo.co.id
}

\begin{abstract}
Abstrak
Penyampaian makalah ini bertujuan untuk menambah wawasan guru dan calon guru dalam melaksanakan pembelajaran matematika dengan menggunakan kearifan lokal melalui pendekatan Contekstual Learning. Kearifan lokal merupakan jawaban kreatif terhadap situasi geografis-geopolitis, historis dan situasional yang bersifat lokal. Sedangkan tujuan pelajaran matematika yang disebutkan dalam lampiran Permendiknas No. 20 tahun 2006 tentang standar isi disebutkan antara lain, agar siswa memiliki kemampuan mengkomunikasikan gagasan dengan simbol, tabel diagram atau media lain untuk memperjelas keadaan atau masalah dan memiliki sifat menghargai kegunaan matematika dalam kehidupan, yaitu memiliki rasa ingin tahu, perhatian dan minat dalam mempelajari matematika serta sifat ulet dan percaya diri dalam pemecahan masalah. Dengan mengintegrasi kearifan lokal dalam pembelajaran matematika melalui pendekatan contekstual learning berarti guru atau calon guru mengupayakan secara maksimal untuk tercapainya tujuan pelajaran matematika sesuai aturan perundangan undangan yang berlaku di Indonesia.
\end{abstract}

Kata Kunci: Pembelajaran Matematika, Integrasi Kearifan Lokal, Contekstual Learning

\section{LOCAL INTEGRATION OF MATHEMATICS LEARNING BAGS WITH LEARNING CONTEXTUAL LEARNING APPROACHES}

\begin{abstract}
The submission of this paper aims to increase the insight of teachers and prospective teachers in implementing mathematics learning by using local wisdom through the Contextual Learning approach. Local wisdom is a creative answer to local geographic-geographic, historical and situational situations. Whereas the purpose of the mathematics lessons mentioned in the attachment of Minister of National Education Regulation No. 20 of 2006 concerning the content standards mentioned, among others, so that students have the ability to communicate ideas with symbols, table diagrams or other media to clarify the situation or problem and have the nature of appreciating the usefulness of mathematics in life, namely having curiosity, attention and interest in learning mathematics and tenacity and confidence in problem solving. By integrating local wisdom in learning mathematics through a contextual learning approach means that the teacher or prospective teacher strives maximally to achieve the objectives
\end{abstract}


Integrasi Kearifan Lokal....(Lusiana)

of mathematics lessons in accordance with the prevailing laws and regulations in Indonesia.

Keywords: Mathematics Learning, Integration of Local Wisdom, Contekstual Learning

\section{A. PENDAHULUAN}

Dalam pendidikan proses mendidik, membina, mengendalikan, mengawasi, mempengaruhi dan mentransformasikan ilmu pengetahuan yang dilaksanakan oleh para pendidik kepada anak didik untuk membebaskan kebodohan, meningkatkan pengetahuan dan membentuk kepribadian yang lebih baik dan bermanfaat bagi kehidupan sehari-hari. Menurut Salahudin (2011) terdapat usaha dan upaya oleh para pendidik agar dapat meningkatkan dan mengembangkan serta memajukan kecerdasan dan keterampilan semua orang yang terlibat dalam pendidikan.

Pendidikan di sekolah, dilaksanakan melalui pembelajaran yang berpedoman pada kurikulum yang digunakan, kurikulum yang berubah pembelajaran yang dilakukan tentu ikut menyesuaikan apa yang menjadi tujuannya, seperti halnya dengan pembelajaran matematika di sekolah, bagaimanpun dari zaman old sampai zaman now, matematika masih menjadi momok bagi siswa-siswa yang kecerdasan logika matematikanya di bawah rata-rata, Oleh karena itu menjadi tugas guru maupun calon guru untuk dapat menyampaikan materi kepada siswa agar siswa memiliki kemampuan-kemampuan yang menjadi tujuan dalam pembelajaran yang dilakukan.

Seperti tujuan-tujuan pelajaran matematika yang. disebutkan dalam lampiran Permendiknas No. 20 tahun 2006 tentang standar isi di antaranya, agar siswa memiliki kemampuan mengkomunikasikan gagasan dengan simbol, tabel diagram atau media lain untuk memperjelas keadaan atau masalah dan memiliki sifat menghargai kegunaan matematika dalam kehidupan, yaitu memiliki rasa ingin tahu, perhatian dan minat dalam mempelajari matematika serta sifat ulet dan percaya diri dalam memecahkan masalah. 
Untuk mencapai hal tersebut diperlukan media pembelajaran,sumber belajar, pendekatan pembelajaran yang sesuai dengan situasi dunia nyata siswa serta lingkungan yang ada di kehidupannya. Seperti pendekatan pembelajaran kontekstual yang dikatakan Riyanto (2014:159) bahwa suatu konsep belajar yang membantu guru mengaitkan antara materi yang diajarkannya dengan situasi dunia nyata siswa dan mendorong antara pengetahuan yang dimilikinya dengan penerapan dalam kehidupan mereka sebagai anggota keluarga dan masyarakat. Dalam pendidikan matematika siswa harus mampu diarahkan untuk menggunakan berbagai situasi dan kesempatan untuk menemukan kembali matematika dengan cara mereka sendiri. Dengan pendekatan kontekstual guru dapat memanfaatkan situasi nyata yang ada di lingkungan siswa, seperti kearifan lokal yang ada di suatu daerah.

Di daerah Sumatera Selatan misalnya, di kota Palembang, banyak kearifan lokal yang dapat menjadi konteks materi-materi matematika yang dibahas, seperti materi SPLDV, Geometri, Aritmatika, statistik. Karena kompetensi-kompetensi yang diharapkan melalui pelajaran matematika yaitu kemampuan pemahaman konsep, berfikir kreatif, penalaran, komunikasi, pemecahan masalah, dan lain-lain, sulit untuk mencapainya jika pembelajarannya dilakukan secara monoton, textbook atau hanya dengan ceramah saja, tanpa media pembelajaran, sumber pembelajaran yang tidak sesuai atau tidak dekat dengan situasi atau dunia nyata siswa. Oleh karena itu, pada kesempatan ini penulis bertujuan untuk mengajak guru dan calon guru menambah wawasan dalam mengembangkan pembelajaran matematika melalui pendekatan contekstual learning menggunakan kearifan lokal yang ada di Palembang. Untuk itu, permasalahan yang akan dikemukakan dalam tulisan ini, penulis merumuskan permasalah sebagai berikut:

1. Pembelajaran matematika pada materi matematika apa saja yang dapat dilaksanakan dengan pendekatan kontekstual?.

2. Kearifan lokal Palembang apa saja yang dapat digunakan ataupun diintegrasikan sebagai konteks dalam pembelajaran matematika?. 
3. Bagaimana sebaiknya menggunakan kearifan lokal sebagai media ataupun konteks dalam pembelajaran matematika?.

Adapun manfaat yang diharapkan dari pembahasan dalam tulisan ini, dapat dijadikan masukan bagi guru dan calon guru dalam mengembangkan pembelajaran matematika dengan mengintegrasikan kearifan lokal melalui pendekatan contekstual learning, dan dapat memperkaya sumber ataupun media dalam pembelajaran matematika

\section{B. Integrasi Kearifan Lokal dalam Pembelajaran Matematika melalui Pendekatan Contekstual Learning \\ Pembelajaran Matematika}

Gravemeijer (1994) menyatakan bahwa matematika merupakan aktivitas manusia. Aktivitas yang dimaksud adalah mencari dan menyelesaikan masalah, serta mengorganisasi materi. Dengan memaknai pernyataan tersebut, sudah saatnya pendidikan matematika berubah dari pembelajaran yang bersifat texstual menuju pembelajaran dengan situasi realistis, penemuan solusi yang didapatkan melalui konstruksi prosedur siswa, dan interaksi dengan siswa lain atau guru., selanjutnya Gravemeijer mengatakan "Penekanan pada gagasan Matematika sebagai aktivitas manusia: Ini adalah aktivitas memecahkan masalah, mencari masalah, tetapi juga merupakan kegiatan mengorganisir materi pelajaran. Ini bisa menjadi masalah dari kenyataan yang harus diatur menurut pola Matematika jika masalah dari realitas harus dipecahkan. Hal ini juga bisa menjadi masalah Matematika, baru atau hasil, dari Anda sendiri atau orang lain, yang harus diatur sesuai dengan ide-ide baru, untuk dipahami lebih baik, dalam konteks yang lebih luas, atau dengan pendekatan aksiomatik".

Pembelajaran matematika dilaksanakan dengan berbagai Model, strategi, pendekatan, metode maupun teknik pembelajaran, Pada kurikulum 2004, pembelajaran matematika ditekankan dengan pendekatan kontekstual, setelah Kurikulum 2013 pada implementasinya ada perubahan pada elemen proses pembelajaran, dimana Standar Proses yang semula terfokus pada eksplorasi, elaborasi, dan konfirmasi dilengkapi dengan mengamati, menanya, mengolah, 
menyajikan, menyimpulkan, dan mencipta. Belajar tidak hanya terjadi di ruang kelas, tetapi juga di lingkungan sekolah dan masyarakat. Guru bukan satu-satunya sumber belajar. Sikap tidak diajarkan secara verbal, tetapi melalui contoh dan teladan. Dengan peubahan ini memungkinkan situasi lingkungan dan masyarakat dapat menjadi sumber belajar bagi siswa selain guru.

Khusus pada pembelajaran matematika, ada 7 perubahan pada implementasi kurikulum lama dengan kurikulum baru, dua di antaranya banyak rumus yang harus dihafal untuk menyelesaikan permasalahan (hanya bisa menggunakan), sedangkan yang baru rumus diturunkan oleh siswa, yang diajukan harus dapat dikerjakan siswa hanya dengan rumus-rumus dan pengertian dasar (tidak hanya bisa menggunakan tetapi juga memahami asal-usulnya). Yang kedua pada kurikulum lama permasalahan matematika selalu diasosiasikan dengan direduksi menjadi angka sedang yang baru perimbangan antara matematika dengan angka dan tanpa angka [gambar, grafik, pola, dsb]. Perubahan perubahan ini tentu tidak dapat dicapai dengan sumber belajar yang terbatas, ataupun pendekatan yang konvensional, jadi guru juga dapat memanfaatkan pendekatan contekstual learning agar situasi lingkungan dan masyarakat dapat menjadi sumber belajar selain guru.

\section{Pendekatan Contekstual Learning}

Pendekatan pembelajaran dapat berarti aturan pembelajaran yang berusaha meningkatkan kemampuan-kemampuan kognitif, afektif dan psikomotorik siswa dalam pengolahan pesan sehingga tercapai sasaran belajar. Kata contekstual berasal dari kata contex yang berarti hubungan, konteks, suasana atau keadaan, Jadi dapat disimpulkan bahwa contekstual merupakan hubungan suasana atau situasi tertentu. Menurut Johnson (2009:35), pembelajaran dan pengajaran kontekstual melibatkan para siswa dalam aktivitas penting yang membantu mereka mengaitkan pelajaran akademis dengan konteks kehidupan nyata yang mereka hadapi.

Selanjutnya, Trianto dalam Dahlan (2017) menyatakan bahwa Pendekatan contekstual learning ( CTL) merupakan konsep belajar yang membantu guru 
Integrasi Kearifan Lokal....(Lusiana)

mengaitkan antara materi yang didaftarkan dengan situasi dunia nyata siswa dan mendorong siswa membuat hubungan antara pengetahuan yang dimilikinya dengan penerapan dalam kehidupan mereka sebagai anggota keluarga dan masyarakat. Dengan konsep itu, hasil pembelajaran yang diharapkan lebih bermakna bagi siswa. Proses pembelajaran berlangsung alamiah dalam bentuk kegiatan siswa bekerja dan mengalami, bukan mentransfer pengetahuan dari guru ke siswa.

\section{Integrasi Kearifan Lokal}

Kearifan lokal merupakan bagian dari budaya suatu masyarakat yang tidak dapat dipisahkan dari bahasa masyarakat itu sendiri. Kearifan lokal (local wisdom) biasanya diwariskan secara turun temurun dari satu generasi ke generasi melalui cerita dari mulut ke mulut.

Kearifan lokal menurut kamus Inggris -Indonesia terdiri dari 2 kata yaitu kearifan (wisdom) dan lokal (local). Wisdom artinya kebijaksanaan dan local artinya setempat, Jadi local wisdom dapat diartikan sebagai gagasan-gagasan, nilai-nilai pandangan-pandangan setempat yang sifatnya bijaksana, nilai baik yang tertanam dan diikuti oleh anggota masyarakat.

Selanjutnya bentuk kearifan lokal dikategorikan ke dalam dua aspek; pertama kearifan lokal yang berwujud nyata (Tengible) yang meliputi a) Tekstual, beberapa jenis kearifan lokal seperti nilai. Tata cara, ketentuan khusus yang dituangkan ke dalam bentuk catatan terulis seperti yang ditemui dalam kitab tradisional primbon, kalender dan prasasti atau budaya tulis di atas lembaran daun lontar, b) bangunan/ arsitektur misalnya, rumah limas, monumen AMPERA.

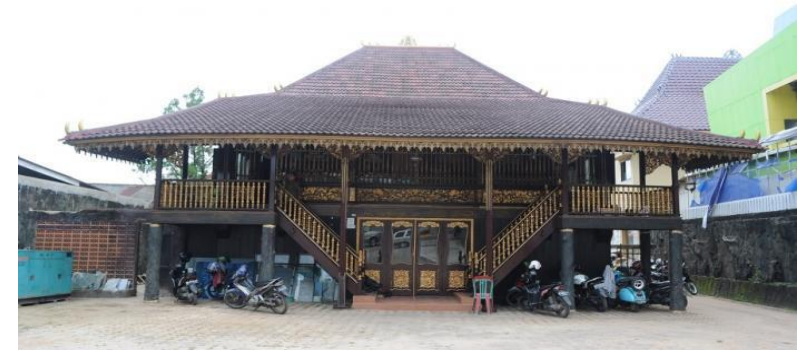

Gambar 1. Rumah Limas 
Untuk gambar Rumah limas dapat diintegrasikan dalam pembelajaran matematika pada materi Geometri dan materi Trigonometri

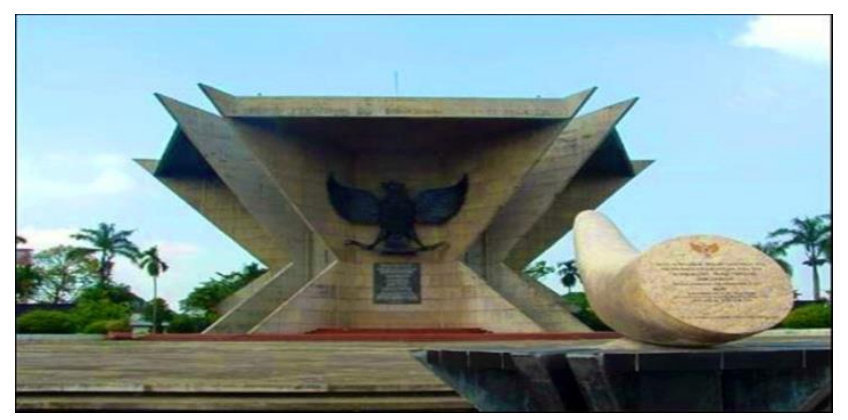

Gambar 2. Monumen AMPERA

Untuk gambar Monumen AMPERA dapat diintegrasikan dalam pembelajaran matematika juga pada materi Geometri dan Trigonometri

c) Benda cagar Budaya/tradisional (karya Seni), misalnya songket Palembang, tarian gending sriwijaya, dan lain sebagainya.

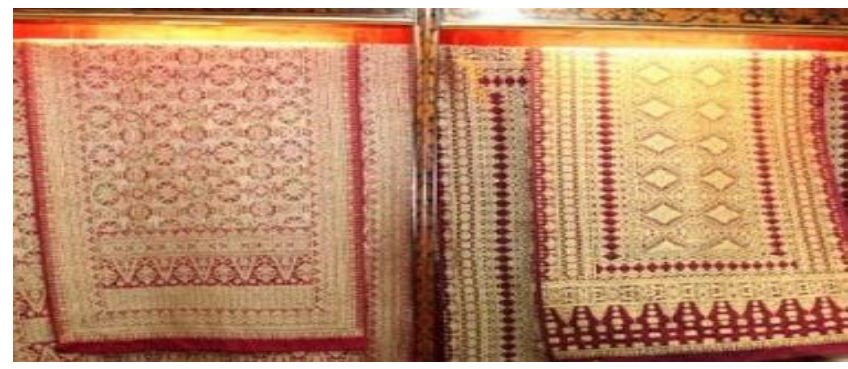

Gambar 3. Songket Palembang

Untuk songket palembang dapat diintegrasikan dalam pembelajaran matematika pada materi Aljabar, materi Aritmatika dan materi geometri .

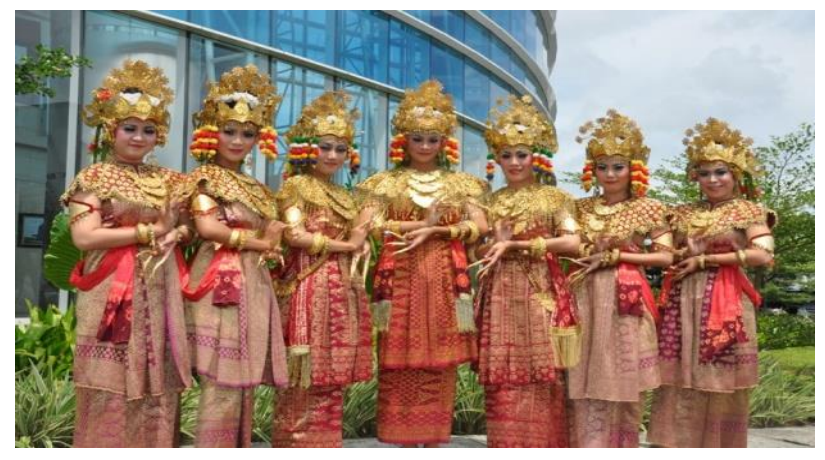

Gambar 4. Penari Gending Sriwijaya 
Untuk Jumlah penari gending sriwijaya biasa dilakukan dengan jumlah yang ganjil; 1 orang, 3 orang, 5 orang, 7 Orang dan seterusnya, jadi dapat di integrasikan dalam pembelajaran matematika masalah pola bilangan, juga dapat membahas masalah kesimetrisan pola gerakan tari yang dilakukan.

Bentuk kearifan lokal yang kedua yaitu yang tidak berwujud (Intangible) seperti petuah yang disampaikan secara verbal dan turun menurun yang bisa berupa cerita rakyat, peribahasa, lagu dan permainan rakyat, jajuluk (gelar yang diterima pasangan pengantin) yang diberikan oleh tetuah-tetuah adat setempat.

Kearifan lokal sebagai sumber pengetahuan yang ditemukan masyarakat lokal tertentu melalui kumpulan pengalaman dalam mencoba dan di integrasikan dengan pemahaman terhadap suatu konsep pembelajaran, seperti dalam pembelajaran bahasa, matematika, IPS maupun IPA. Dalam pembelajaran matematika, seperti yang dikatakan Sartini dalam Wuri Wuryandani (2017) bahwa Kearifan lokal sangat banyak fungsinya, dua diantaranya berfungsi untuk pengembangan sumber daya manusia.dan berfungsi untuk pengembangan kebudayaan dan ilmu pengetahuan

\section{Integrasi Kearifan Lokal dalam Pembelajaran Matematika melalui Pendekatan Contekstual Learning}

Matematika adalah ilmu dari segala ilmu, tidak ada suatu pekerjaan yang tidak menggunakan matematika baik dibidang ekonomi, pertanian dan pertambangan serta dibidang lainnya. Oleh sebab itu, pelajaran matematika sangat penting bagi kita. Selain itu juga matematika selalu kita jumpai dalam kehidupan kita baik di sekolah maupun dalam kehidupan sehari-hari.

Matematika perlu dikaitkan dengan kenyataan yang berada dekat dengan siswa dan relevan dengan kehidupan masyarakat agar memiliki nilai manusiawi. Materi matematika harus dapat ditransmisikan sebagai aktifitas manusia (human activity). Kesempatan siswa yang diberikan melalui Pendidikan untuk reinvent (menemukan/menciptakan) matematika melalui praktek (doing it). Sehingga 
dalam pendidikan matematika, pembelajaran matematika bukan merupakan sistem yang tertutup tetapi sebagai suatu aktivitas dalam proses matematisasi.

Dengan mengintegrasikan Kearifan Lokal dalam pembelajaran matematika yang bersifat deduktif-aksiomatif. Objek-objek matematika yang ada di alam pikiran manusia, berupa fakta, konsep, prinsip, dan skill akan muncul sehingga memperkuat kemampuan pemahaman, penalaran, kreatif, kritis dan komunikatif dalam memecahkan permasalahan yang dihadapi. Irianto (2009) mengatakan bahwa pendidikan berbasis kearifan lokal dapat dikatakan sebagai model pendidikan yang memiliki relevansi tinggi bagi pengembangan kecakapan hidup (life skills), dengan bertumpu pada pemberdayaan keterampilan dan potensi lokal di masing-masing daerah. Materi pembelajaran juga harus memiliki makna dan relevansi tinggi terhadap pemberdayaan hidup mereka secara nyata, berdasarkan realitas yang dihadapi. Kurikulum yang harus disiapkan adalah kurikulum yang sesuai dengan kondisi lingkungan hidup, minat, dan kondisi peserta didik.

Contoh situasi dan kondisi lingkungan siswa SMP di daerah palembang, yang dalam kondisi masa pertumbuhan, yang hobinya makan atau pun ngemil, seperti kuliner yang dikenal di daerah palembang, yang terbuat dari ikan, dan tepung terigu, yang bergizi banyak mengandung karbohidrat dan protein, makanan ini sangat digemari oleh masyarakat Palembang, dari anak-anak sampai dewasa bahkan sampai tua, tetap menyukai jenis makanan ini.

Artinya makanan ini sangat di kenal oleh siswa di daerah palembang, tentu konteks ini sangat cocok untuk menjadi sumber belajar matematika, yang mengintegrasikan kearifan lokal melalui pendekatan contekstual learning dengan materi himpunan, SPLDV, Aritmatika, Aljabar dalam materi fungsi, Statistik, dan lain-lain. Begitu banyak materi matematika yang pembelajaranmya dapat mengintegrasikan konteks yang berupa kearifan lokal pada daerah setempat.

\section{SIMPULAN}

Berdasarkan pembahasan dalam makalah ini dapat disimpulkan bahwa hampir semua materi matematika (Aljabar, Aritmatika, Statistik, Geometri dan Trigonometri) 
Integrasi Kearifan Lokal....(Lusiana)

dapat menggunakan pendekatan contekstual learning dalam penyajiannya untuk mencapai tujuan seperti yang diharapkan dalam kurikulum 2013.

Kearifan lokal Palembang yang dapat di integrasikan dalam pembelajaran matematika merupakan kearifan lokal yang berwujud nyata (Tengible) yang meliputi a) Tekstual, beberapa jenis kearifan lokal seperti nilai. Tata cara, ketentuan khusus yang dituangkan ke dalam bentuk catatan terulis seperti yang ditemui dalam kitab tradisional primbon, kalender dan prasasti atau budaya tulis di atas lembaran daun lontar, b) bangunan/ asrsitektur misalnya, rumah limas, monumen AMPERA. c) Benda cagar Budaya/tradisional (karya Seni), misalnya songket Palembang, tarian gending sriwijaya, dan lain sebagainya

Untuk menggunakan kearifan lokal sebagai media ataupun konteks dalam pembelajaran matematika, guru atau calon guru dapat melaksanakannya dengan menggunakan pendekatan contekstual learning, karena melalui pendekatan ini kearifan lokal yang menjadi sumber pembelajaran yang dekat dengan situasi dunia nyata siswa.

\section{DAFTAR PUSTAKA}

Dahlan A. (2017) www.sekolahpendidikan.com/2017/10/18-pengertian-kearifanlokal-ciri.htmlvvv diakses 29 April 2018.

Gravemeijer, K. (1994). Developing Realistic Mathematics Education. Ultrecht: Freudenthal Institute.

https://id.wikipedia.org/wiki/Kearifan_lokal

https://www.sekolahpendidikan.com/2017/10/18-pengertian-kearifan-lokalciri.htmlvvv

Irianto. (2009). Model-model Pembelajaran Inovatif Beorientasi Kontruktivisme. Jakarta: Prestasi Pustaka

Johnson, B. E. (2009). Contextual Teaching \& Learning. Bandung: MLC

Riyanto, H. Y. (2014). Paradigma Baru Pembelajaran. Jakarta: Kencana .

Salahuddin M. (2011). Modul Pembelajaran Rekayasa Perangkat Lunak (Terstruktur dan Berorientasi Objek), Modula, Bandung.

Sartini. (2006). Menggali Kearifan Lokal Nusantara Sebuah kajian Filsafati. http://filsafat.ugm.ac.id diakses tanggal 30 April 2018.

Undang-Undang No. 20 tahun 2006 Tentang Sistem Pendidikan Nasional (Sisdiknas). 